\title{
Preconcentration and atomic spectrometric determination of rare earth elements (REEs) in natural water samples by inductively coupled plasma atomic emission spectrometry
}

\author{
Türker Pasinli, Ahmet E. Eroğlu*, Talal Shahwan \\ Department of Chemistry, İzmir Institute of Technology, 35430 Urla-İzmir, Turkey
}

Received 31 October 2004; received in revised form 25 April 2005; accepted 27 April 2005

Available online 31 May 2005

\begin{abstract}
The usage of a variety of sorbents has been shown as promising matrix removal/preconcentration strategies for the determination of rare earth elements (REEs) in various natural water samples by inductively coupled plasma atomic emission spectrometry (ICP-AES). The sorption efficiency of various zeolites (clinoptilolite, mordenite, zeolite Y, zeolite Beta), ion-exchangers (Amberlite CG-120, Amberlite IR-120, Rexyn 101, Dowex 50W X18) and chelating resins (Muromac, Chelex 100, Amberlite IRC-718) towards REEs was investigated in terms of solution $\mathrm{pH}$, shaking time and sorbent amount. The results have shown that most of the materials can take up REEs at a wide $\mathrm{pH}$ range. The experiments were continued with clinoptilolite, zeolite $\mathrm{Y}$ and Chelex 100 and it was demonstrated that all three materials displayed very fast kinetics for REE sorption (higher than $96 \%$ in $1 \mathrm{~min}$ ). Desorption from the sorbents was realized with $2.0 \mathrm{M} \mathrm{HNO}_{3}$ for clinoptilolite and $0.1 \mathrm{M} \mathrm{HNO}_{3}$ for zeolite $\mathrm{Y}$ and Chelex 100. Only the lower concentration range (0.01-2.0 $\left.\mathrm{mg}^{-1}\right)$ of matrix-matched standards were used in quantitation although the calibration graphs were linear at least up to $10.0 \mathrm{mg} \mathrm{l}^{-1}$ for all REEs studied. The limit of detection $(3 \mathrm{~s})$ without preconcentration was $0.1,1.0$, and $0.2 \mu \mathrm{gl}^{-1}$ for Eu, La, and $\mathrm{Yb}$, respectively. The validity of the method with the selected sorbents was checked through spike recovery experiments.
\end{abstract}

(C) 2005 Elsevier B.V. All rights reserved.

Keywords: Rare earth elements; Inductively coupled plasma atomic emission spectrometry (ICP-AES); Preconcentration; Clinoptilolite; Zeolite Y; Chelex 100

\section{Introduction}

Rare earth elements (REEs) are used in industrial applications due to their metallurgical, optical and electronic properties. The rising use of the REEs in industry, and thus increasing the possibility of their release into the environment, has necessitated the development of new sensitive, precise and accurate analytical methods for their determination in various environmental matrices including water.

There have been many analytical techniques used for the determination of REEs in solid and solution samples; neutron activation analysis [1,2], isotope dilution mass spectrometry $[3,4]$, inductively coupled plasma atomic emission spectrom-

\footnotetext{
* Corresponding author. Tel.: +90 232750 7533; fax: +90 2327507509 .

E-mail address: ahmeteroglu@iyte.edu.tr (A.E. Eroğlu).
}

etry (ICP-AES) [5-9], and inductively coupled plasma mass spectrometry (ICP-MS) [10-16] are the most popular ones. These techniques are usually applied after a separation and/or a preconcentration step due to low concentrations of REEs in environmental samples. Also, major constituents in several samples, such as organic compounds and inorganic salts, may result in interference effects. Various methods have been used for matrix removal/preconcentration purposes, such as coprecipitation [4], liquid-liquid extraction [17,18], ion-exchange $[7-9,13]$, and a variety of sorbents including chelating resins $[5,6,10-12,15,19,20]$.

A high number of the materials recommended in REE studies can be suitable candidates for the substrates in solid phase extraction (SPE) methods. The simplicity, ease of availability and compatibility of SPE methods with different measurement techniques make them proper alternatives for 
expensive and time-consuming separation/preconcentration procedures. For example, Liang et al. [6] used a microcolumn of $\mathrm{TiO}_{2}$ for the on-line preconcentration of $\mathrm{La}, \mathrm{Y}, \mathrm{Yb}$, $\mathrm{Eu}$, Dy. Rucandio [7] applied Dowex 50W X18, a strong cation-exchange resin, to separate REEs from $\mathrm{Ba}$. The same resin was used by Djingova and Ivanova [8] for the separation of REEs from the matrix elements in the soil and sediment extracts. Resins with iminodiacetate functional groups have also been used in REE studies. In one of these studies, Hirata et al. [11] utilized a microcolumn of Muromac A-1 resin for the preconcentration and determination of REEs in sea water. Inagaki and Haraguchi [12] employed a preconcentration step with Chelex 100 (another very popular chelating resin with iminodiacetate functionality) to human blood serum for the determination of REEs whereas Möller et al. [20] used Chelex 100 for onboard preconcentration of REEs from sea water. Willie and Sturgeon [21] determined the REEs in sea water by utilizing a microcolumn of Toyopearl AF Chelate $650 \mathrm{M}$, a chelating resin with iminodiacetate functional groups, prior to inductively coupled plasma time of flight mass spectrometric determination. Amberlite XAD resins are also among the well-known adsorbents applied in the preconcentration of REEs, either with direct use or employed after a suitable functionalization step. For example, Dev et al. [22] investigated the sorption behavior of $\mathrm{La}(\mathrm{III}), \mathrm{Nd}(\mathrm{III}), \mathrm{Tb}(\mathrm{III}), \mathrm{Th}(\mathrm{IV})$ and $\mathrm{U}(\mathrm{VI})$ on Amberlite XAD-4 resin functionalized with bicine ligands. De Vito et al. [23] functionalized XAD-7 with thorin and used the resin for REE preconcentration prior to X-ray fluorescence determination. Vicente et al. [10] followed a different strategy and preconcentrated the oxine complexes of some REEs on Amberlite XAD-7 resin. More information on the determination of REEs and other metals can be found in reviews [24,25].

The aim of the present study was to investigate the sorption behavior of various zeolites (clinoptilolite, mordenite, zeolite Y, zeolite Beta), ion-exchangers (Amberlite CG-120, Amberlite IR-120, Rexyn 101, Dowex 50W X18) and chelating resins (Muromac, Chelex 100, Amberlite IRC-718) towards REEs in terms of solution $\mathrm{pH}$, shaking time, and sorbent amount; and to make some conclusions about their applicability to matrix removal/preconcentration purposes in natural water samples.

\section{Experimental}

\subsection{Instrumentation and apparatus}

A Varian Liberty Series II Axial view ICP-AES was used in all measurements. The instrument was operated applying an incident power of $1.2 \mathrm{~kW}$, a plasma gas (Ar) flow rate of $151 \mathrm{~min}^{-1}$, a sampling gas flow rate of $0.91 \mathrm{~min}^{-1}$ and an auxiliary gas (Ar) flow rate of $1.51 \mathrm{~min}^{-1}$. Continuous nebulization at a sampling flow rate of $1.4 \mathrm{ml} \mathrm{min}^{-1}$ was applied during the measurements by means of a concentric glass nebulizer equipped with cyclonic spray chamber.
Quantitative measurements were based on the evaluation of peak height measurements. Background correction was realized by utilizing the polynomial plot method. The REEs investigated and their emission wavelengths were as follows: Ce $(413.380 \mathrm{~nm})$, Dy $(353.170 \mathrm{~nm}), \operatorname{Er}(337.276 \mathrm{~nm})$, $\mathrm{Eu}(420.505 \mathrm{~nm}), \mathrm{Gd}(342.247 \mathrm{~nm})$, Ho $(345.600 \mathrm{~nm})$, La $(379.478 \mathrm{~nm}), \mathrm{Nd}(460.109 \mathrm{~nm}), \operatorname{Pr}(390.844 \mathrm{~nm}), \mathrm{Tb}$ $(350.917 \mathrm{~nm}$, and $\mathrm{Yb}(369.419 \mathrm{~nm})$. In batch sorption studies, Yellowline RS 10 (Staufen, Germany) lateral shaker was used to provide efficient mixing. $\mathrm{pH}$ measurements were performed using a Corning $450 \mathrm{pH} / \mathrm{ion}$ meter with a $\mathrm{pH}$ combination electrode.

\subsection{Reagents and materials}

All reagents were of analytical grade. Ultra pure water $(18 \mathrm{M} \Omega$ ) was used throughout the study. All reagents were stored in polyethylene/polypropylene containers. Plastic ware was soaked in $10 \%(\mathrm{v} / \mathrm{v})$ nitric acid for cleaning and rinsed with ultra pure water prior to use. Standard multielement REEs stock solution (1000 $\mathrm{mg} \mathrm{l}^{-1}$ ) were prepared by dissolving the appropriate amount of oxide or nitrate forms of the REEs in $100 \mathrm{ml}$ of ultra pure water. $\mathrm{pH}$ buffers, ranging from 2 to 10 , were prepared using various concentration of potassium hydrogen phthalate $\left(\mathrm{KHC}_{8} \mathrm{H}_{4} \mathrm{O}_{4}\right)$, potassium phthalate $\left(\mathrm{K}_{2} \mathrm{C}_{8} \mathrm{H}_{4} \mathrm{O}_{4}\right), \mathrm{NaOH}, \mathrm{HCl}$, and $\mathrm{Na}_{2} \mathrm{~B}_{4} \mathrm{O}_{7}$. Clinoptilolite-rich natural zeolite mineral used in this study was obtained from Enli Mining Co. (from deposits in Gördes, Turkey). Other adsorbents studied are listed in Table 1.

\subsection{Sorption studies}

Sorption characteristics of the potential sorbents for REEs were examined by a batch process in a way that, $20.0 \mathrm{ml}$ of REE solution in the prescribed concentration was prepared and $0.1 \mathrm{~g}$ of the selected sorbent was added into this solution. The mixture was shaken for 1-2 min manually and then placed on a lateral shaker for $30 \mathrm{~min}$ at room temperature. After the shaking period, the solid and the liquid phases were separated by filtration and the liquid part was analyzed for REEs by ICP-AES. The solid portion was put into $2.0 \mathrm{M}$ $\mathrm{HNO}_{3}$ in the case of clinoptilolite or $0.1 \mathrm{M} \mathrm{HNO}_{3}$ in the cases of zeoliteY and Chelex 100 and shaken as before for further $30 \mathrm{~min}$ for the desorption of REEs. After filtration, the filtrate was analyzed as described.

For the examination of the effect of solution $\mathrm{pH}$ on the sorption of REEs by the selected sorbents, $1.0 \mathrm{mg} \mathrm{l}^{-1}$ multielement REE standard was prepared in $\mathrm{pH}$ buffer solutions ( $\mathrm{pH}=2.0-10.0)$ at a constant ionic strength, and the usual sorption procedure was employed. For the adjustment of $\mathrm{pH}$, $\mathrm{NH}_{3}(0.1-1.0 \mathrm{M})$ and $\mathrm{HCl}(0.1-1.0 \mathrm{M})$ were used. Similar experiments were also performed in different $\mathrm{HNO}_{3}$ concentrations $(0.5-4.0 \mathrm{M})$. Percent sorption values as a function of $\mathrm{pH}$ and $\mathrm{HNO}_{3}$ concentration were calculated from the concentration of REEs in the filtrate. Similar experiments were 
Table 1

Sorbents investigated in this study and proper $\mathrm{pH}$ ranges for efficient uptake

\begin{tabular}{|c|c|c|c|}
\hline Type & Sorbent & Functional groups & $\mathrm{pH}$ range $\mathrm{a}^{\mathrm{a}}$ \\
\hline \multirow{4}{*}{ Strong cation exchanger } & Dowex 50W X18 & Sulfonic acid groups & $\sim 0.4-6$ \\
\hline & Rexyn 101 & Sulfonic acid groups & $\sim 0.4-5$ \\
\hline & Amberlite CG-120 & $\mathrm{Na}^{+}$form, sulfonic acid groups & $\sim 0.4-10$ \\
\hline & Amberlite IR-120 & $\mathrm{H}^{+}$form, sulfonic acid groups & $\sim 0.4-5$ \\
\hline \multirow{3}{*}{ Chelating resin } & Amberlite IRC-718 & $\mathrm{Na}^{+}$form, iminodiacetate groups & $2-5$ \\
\hline & Chelex 100 & $\mathrm{Na}^{+}$form, iminodiacetate groups & $3-10$ \\
\hline & Muromac & Iminodiacetate groups & $1-5$ \\
\hline \multirow{4}{*}{ Zeolite } & Clinoptilolite (natural) & $\mathrm{b}$ & $4-10$ \\
\hline & Zeolite Y (synthetic) & Ammonium form & $4-10$ \\
\hline & Zeolite Beta (synthetic) & Ammonium form & $4-10$ \\
\hline & Mordenite (synthetic) & Ammonium form & $5-10$ \\
\hline
\end{tabular}

a Useful $\mathrm{pH}$ range for the uptake of REEs.

b Approximate chemical composition: $\left.(\mathrm{K}, \mathrm{Na}, 1 / 2 \mathrm{Ca})_{2} \mathrm{O} \cdot \mathrm{Al}_{2} \mathrm{O}_{3} \cdot 10 \mathrm{SiO}_{2} \cdot 8 \mathrm{H}_{2} \mathrm{O}\right)$.

carried out to determine the optimum shaking time and the amount of sorbent for a quantitative sorption.

Since the present study describes the possibility of using clinoptilolite, in addition to the other sorbents, for matrix removal/preconcentration purposes prior to ICP-AES determination of REEs, equilibrium sorption isotherm studies were also conducted over a wide range of concentrations in order to investigate the sorption behavior of REEs on clinoptilolite. These studies were also carried out by a batch process in a way that $0.100 \mathrm{~g}$ clinoptilolite was added into $20.0 \mathrm{ml}$ of solutions containing the specified concentrations of REEs (ranging from 1.0 to $100.0 \mathrm{mg} \mathrm{l}^{-1}$ ) and the mixtures were shaken at room temperature for $30 \mathrm{~min}$. At the end of the shaking period, the solid and the liquid phases were separated by filtration and the liquid part was analyzed by ICPAES for REEs, as explained before. The amount of REEs sorbed per unit mass of clinoptilolite was determined from the mass balance.

\section{Results and discussion}

The results of the experiments carried out in the present study under the specified conditions have shown very strong similarities among REEs. Therefore, the results for only La are given in the subsequent sections except Section 3.6 in which a comparison is made based on the affinity of clinoptilolite towards $\mathrm{La}$ (a light REE), Eu (a medium REE), and $\mathrm{Yb}$ (a heavy REE).

\subsection{Calibration}

In the initial stages of the study, the effect of solution matrix after the sorption/desorption step employed on the ICP-AES signal of the REEs was examined. For this purpose, two types of calibration graphs were prepared, i.e., either with aqueous, or with matrix-matched standard solutions. The matrix-matched calibration graph was ob- tained by applying the proposed sorption/desorption steps with each adsorbent. For example, for clinoptilolite, $20.0 \mathrm{ml}$ standard solutions from 0.01 to $2.0 \mathrm{mg}^{-1}$ were mixed with clinoptilolite and the usual sorption/desorption step was applied; $20.0 \mathrm{ml}$ of $\mathrm{HNO}_{3}$ was the desorbing solution. In this way, any possible suppression effect from the treated sorbent was expected to be eliminated. For La, calibration line equations (and correlation coefficients) for aqueous and matrix-matched standards were: $y=5.1 \times 10^{4} x+550$ $\left(R^{2}=0.9999\right)$ and $y=4.0 \times 10^{4} x+135\left(R^{2}=0.9996\right)$, respectively. As can be seen, the calibration sensitivity (the slope of the calibration plot) is affected from sorption/desorption step and the matrix-matched standards always gave sensitivity approximately $20 \%$ lower than those of aqueous standards. This result was expectable when the "percentage sorption versus $\mathrm{pH}$ and acidity" graph is examined in the following section.

\subsection{Effect of pH on sorption}

The effect of solution $\mathrm{pH}$ on the sorption of REEs on the sorbents was investigated as explained in Section 2.3. As can be seen in Fig. 1, a pH range is generally available for any sorbent, over which it demonstrates an efficient sorption capability. The most appropriate $\mathrm{pH}$ ranges for the investigated sorbents under the experimental conditions employed in this study are given in Table 1. This table (together with Fig. 1) can be considered as a rough guide in deciding the working $\mathrm{pH}$ for various samples having different $\mathrm{pH}$ values. Keeping in mind the other parameters affecting the sorption, it can be said that the zeolites (clinoptilolite, mordenite, zeolite $\mathrm{Y}$ and zeolite Beta) can be used for matrix removal/preconcentration during the determination of REEs in neutral solutions. The choice should be based on the expected concentration of REEs in the sample, the background REE levels in the sorbent, and also the availability of the sorbent. The lower the background REE level of the sorbent (the purer the material), the higher the possibility of its use in the trace/ultra 

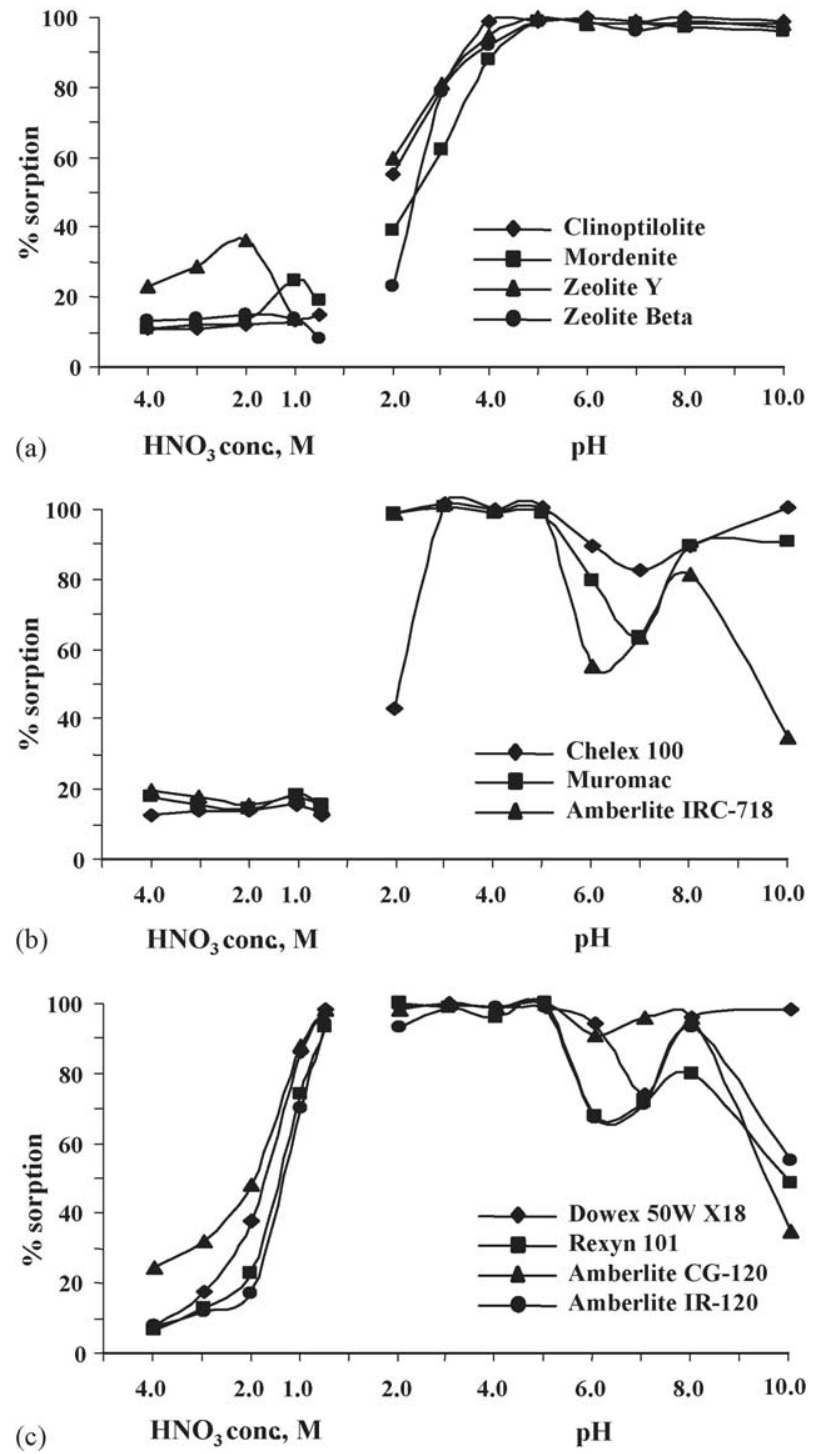

Fig. 1. $\mathrm{La}(\mathrm{III})$ sorption as a function of $\mathrm{pH}$ and $\mathrm{HNO}_{3}$ concentration on different sorbents: (a) zeolites, (b) chelating resins, and (c) ion-exchangers.

trace preconcentration applications. Clinoptilolite, in this respect, can be a good matrix removal/preconcentration material only for REE concentrations higher than $0.02 \mathrm{mg} \mathrm{l}^{-1}$. Due to the possibility of desorbing some REEs which are naturally present in clinoptilolite, it cannot be applied for lower concentrations; or the analyst can find an efficient purification method. Another observation in Fig. 1 is that the strong cation exchangers (Amberlite CG-120, Amberlite IR120, Rexyn 101, Dowex 50W X18) can be employed even at a $\mathrm{HNO}_{3}$ concentration of $0.5 \mathrm{M}$. These resins can be used in the preconcentration of REEs especially from the dissolved solutions of precipitated solids, fusion fluxes, or acid digests.

Since natural waters are considered in this study, any sorbent which has been shown to be working effectively for the uptake of REEs at the $\mathrm{pH}$ of natural waters could be appropriate for the matrix removal/preconcentration step prior to
ICP-AES measurements. Therefore, clinoptilolite, zeolite Y and Chelex 100 were selected and employed in the subsequent studies.

\subsection{Effect of shaking time}

One of the criteria that must be given a high priority in choosing a suitable material for sorption of the analytes in natural water is the fast kinetics of the sorption process. The selected sorbents were examined in this respect and the shaking time was varied between 1 and 120 min. The percentage sorption was higher than 96 for all the three sorbents even after $1 \mathrm{~min}$ manual shaking. The results demonstrated the suitability of the selected sorbents for the matrix removal/preconcentration step. These values are also the indicative of the applicability of the sorbents in SPE cartridges, and mini- or micropacked columns. To ensure attainment of equilibrium, a shaking time of $30 \mathrm{~min}$ was applied in the subsequent studies with batch method.

\subsection{Effect of sorbent amount}

Similar sorption experiments were carried out to determine the optimum amount of the sorbent for $20.0 \mathrm{ml}$ of $1.0 \mathrm{mg} \mathrm{l}^{-1}$ REEs standard solution. The amounts of the sorbents used were: $0.01,0.05,0.10,0.20$, and $0.50 \mathrm{~g}$. Clinoptilolite exhibited very similar sorption behavior for all the amounts investigated $(97( \pm 1) \%)$. Zeolite $\mathrm{Y}$ was not able to show a sufficient sorption with $0.01 \mathrm{~g}(47 \%)$ whereas $0.05 \mathrm{~g}$ gave $93 \%$ sorption. It worked quantitatively (>99\%) beyond $0.10 \mathrm{~g}$. For Chelex 100, percent sorption was $83 \%$ with $0.01 \mathrm{~g}$ and $>99 \%$ with $0.05-0.50 \mathrm{~g}$. The sorption value for $0.01 \mathrm{~g}$ Chelex 100 does not reflect its capacity when used in its original particle size in bead form, possibly because of insufficient solid-to-liquid ratio for a quantitative sorption for a shaking time of $30 \mathrm{~min}$. When the amount of sorbents used in this study is considered $(0.1 \mathrm{~g})$, it can be said that all three sorbents can be good candidates for environmental samples. In terms of economy of the process, the use of clinoptilolite exhibits the best condition.

\subsection{Desorption}

The first canditate for desorbing REEs from the sorbents was $\mathrm{HNO}_{3}$ since the percent sorption values in $\mathrm{HNO}_{3}$ concentrations of $0.5-4.0 \mathrm{M}$ were between 10 and $20 \%$. Very close recoveries were obtained with the $\mathrm{HNO}_{3}$ concentrations applied and 2.0 $\mathrm{M}$ was decided to be used for desorption from clinoptilolite and $0.1 \mathrm{M}$ from Chelex 100 and zeolite Y. It must be noted here that the matrix stability of clinoptilolite at such a high acidic concentration was examined using X-ray diffraction (XRD) and scanning electron microscopy (SEM). The results of both examinations confirmed the structural and morphological stability of the mineral following its exposure to $2.0 \mathrm{M} \mathrm{HNO}_{3}$. 
Table 2

Spike recovery results for ultra pure water ${ }^{\mathrm{a}}$

\begin{tabular}{|c|c|c|c|c|c|c|}
\hline \multirow[t]{2}{*}{$\mathrm{La}(\mathrm{III})$ spike $\left(\mathrm{mg} \mathrm{l}^{-1}\right)$} & \multirow[t]{2}{*}{ Initial volume $(\mathrm{ml})$} & \multirow[t]{2}{*}{ Final volume $(\mathrm{ml})$} & \multirow[t]{2}{*}{ Enrichment factor } & \multicolumn{3}{|c|}{$\mathrm{La}(\mathrm{III})$ found $\left(\mathrm{mg} \mathrm{l}^{-1}\right)$} \\
\hline & & & & Clinoptilolite & Zeolite Y & Chelex 100 \\
\hline 1.00 & 20 & 20 & 1.0 & $>0.99$ & $>0.99$ & $>0.99$ \\
\hline 0.40 & 50 & 20 & 2.5 & $0.85( \pm 0.02)$ & $0.75( \pm 0.03)$ & $0.75( \pm 0.01)$ \\
\hline 0.08 & 250 & 20 & 12.5 & $0.84( \pm 0.03)$ & $0.56( \pm 0.05)$ & $0.70( \pm 0.02)$ \\
\hline 0.04 & 500 & 20 & 25 & $0.83( \pm 0.01)$ & $0.35( \pm 0.02)$ & $0.63( \pm 0.05)$ \\
\hline 0.02 & 1000 & 20 & 50 & $0.77( \pm 0.01)$ & $0.17( \pm 0.01)$ & - \\
\hline \multirow[t]{2}{*}{$\mathrm{Eu}(\mathrm{III})$ spike $\left(\mathrm{mg} \mathrm{l}^{-1}\right)$} & \multirow[t]{2}{*}{ Initial volume (ml) } & \multirow[t]{2}{*}{ Final volume (ml) } & \multirow[t]{2}{*}{ Enrichment factor } & \multicolumn{3}{|c|}{$\mathrm{Eu}(\mathrm{III})$ found $\left(\mathrm{mg} \mathrm{l}^{-1}\right)$} \\
\hline & & & & Clinoptilolite & Zeolite Y & Chelex 100 \\
\hline 1.00 & 20 & 20 & 1.0 & $>0.99$ & $>0.99$ & $>0.99$ \\
\hline 0.40 & 50 & 20 & 2.5 & $0.87( \pm 0.01)$ & $0.77( \pm 0.03)$ & $0.74( \pm 0.01)$ \\
\hline 0.08 & 250 & 20 & 12.5 & $0.82( \pm 0.04)$ & $0.53( \pm 0.04)$ & $0.69( \pm 0.02)$ \\
\hline 0.04 & 500 & 20 & 25 & $0.82( \pm 0.02)$ & $0.33( \pm 0.02)$ & $0.61( \pm 0.05)$ \\
\hline 0.02 & 1000 & 20 & 50 & $0.77( \pm 0.77)$ & $0.16( \pm 0.01)$ & - \\
\hline \multirow[t]{2}{*}{$\mathrm{Yb}(\mathrm{III})$ spike $\left(\mathrm{mg} \mathrm{l}^{-1}\right)$} & \multirow[t]{2}{*}{ Initial volume $(\mathrm{ml})$} & \multirow[t]{2}{*}{ Final volume (ml) } & \multirow[t]{2}{*}{ Enrichment factor } & \multicolumn{3}{|c|}{$\mathrm{Yb}(\mathrm{III})$ found $\left(\mathrm{mg}^{-1}\right)$} \\
\hline & & & & Clinoptilolite & Zeolite Y & Chelex 100 \\
\hline 1.00 & 20 & 20 & 1.0 & $>0.99$ & $>0.99$ & $>0.99$ \\
\hline 0.40 & 50 & 20 & 2.5 & $0.92( \pm 0.01)$ & $0.75( \pm 0.03)$ & $0.80( \pm 0.01)$ \\
\hline 0.08 & 250 & 20 & 12.5 & $0.87( \pm 0.03)$ & $0.62( \pm 0.02)$ & $0.75( \pm 0.02)$ \\
\hline 0.04 & 500 & 20 & 25 & $0.87( \pm 0.02)$ & $0.44( \pm 0.03)$ & $0.70( \pm 0.04)$ \\
\hline 0.02 & 1000 & 20 & 50 & $0.79( \pm 0.02)$ & $0.26( \pm 0.01)$ & - \\
\hline
\end{tabular}

${ }^{\text {a }}$ Recovery results are the average of three separate determinations ( \pm standard deviation).

Table 3

Spike recovery results for bottled drinking water ${ }^{\mathrm{a}}$

\begin{tabular}{|c|c|c|c|c|c|c|}
\hline \multirow[t]{2}{*}{$\mathrm{La}(\mathrm{III})$ spike $\left(\mathrm{mg} \mathrm{l}^{-1}\right)$} & \multirow[t]{2}{*}{ Initial volume (ml) } & \multirow[t]{2}{*}{ Final volume (ml) } & \multirow[t]{2}{*}{ Enrichment factor } & \multicolumn{3}{|c|}{$\mathrm{La}(\mathrm{III})$ found $\left(\mathrm{mg} \mathrm{l}^{-1}\right)$} \\
\hline & & & & Clinoptilolite & Zeolite Y & Chelex 100 \\
\hline 1.00 & 20 & 20 & 1.0 & $>0.99$ & $>0.99$ & $>0.99$ \\
\hline 0.40 & 50 & 20 & 2.5 & $0.83( \pm 0.03)$ & $0.78( \pm 0.04)$ & $0.78( \pm 0.01)$ \\
\hline 0.08 & 250 & 20 & 12.5 & $0.83( \pm 0.04)$ & $0.60( \pm 0.02)$ & $0.62( \pm 0.05)$ \\
\hline 0.04 & 500 & 20 & 25 & $0.82( \pm 0.02)$ & $0.38( \pm 0.01)$ & $0.46( \pm 0.02)$ \\
\hline 0.02 & 1000 & 20 & 50 & $0.79( \pm 0.02)$ & $0.17( \pm 0.01)$ & - \\
\hline \multirow[t]{2}{*}{$\mathrm{Eu}(\mathrm{III})$ spike $\left(\mathrm{mg} \mathrm{l}^{-1}\right)$} & \multirow[t]{2}{*}{ Initial volume (ml) } & \multirow[t]{2}{*}{ Final volume (ml) } & \multirow[t]{2}{*}{ Enrichment factor } & \multicolumn{3}{|c|}{$\mathrm{Eu}(\mathrm{III})$ found $\left(\mathrm{mg} \mathrm{l}^{-1}\right)$} \\
\hline & & & & Clinoptilolite & Zeolite Y & Chelex 100 \\
\hline 1.00 & 20 & 20 & 1.0 & $>0.99$ & $>0.99$ & $>0.99$ \\
\hline 0.40 & 50 & 20 & 2.5 & $0.83( \pm 0.03)$ & $0.80( \pm 0.04)$ & $0.77( \pm 0.01)$ \\
\hline 0.08 & 250 & 20 & 12.5 & $0.81( \pm 0.03)$ & $0.60( \pm 0.02)$ & $0.60( \pm 0.05)$ \\
\hline 0.04 & 500 & 20 & 25 & $0.81( \pm 0.03)$ & $0.35( \pm 0.01)$ & $0.41( \pm 0.03)$ \\
\hline 0.02 & 1000 & 20 & 50 & $0.71( \pm 0.02)$ & $0.15( \pm 0.01)$ & - \\
\hline \multirow[t]{2}{*}{$\mathrm{Yb}(\mathrm{III})$ spike $\left(\mathrm{mg} \mathrm{l}^{-1}\right)$} & \multirow[t]{2}{*}{ Initial volume (ml) } & \multirow[t]{2}{*}{ Final volume (ml) } & \multirow[t]{2}{*}{ Enrichment factor } & \multicolumn{3}{|c|}{$\mathrm{Yb}(\mathrm{III})$ found $\left(\mathrm{mg} \mathrm{l}^{-1}\right)$} \\
\hline & & & & Clinoptilolite & Zeolite Y & Chelex 100 \\
\hline 1.00 & 20 & 20 & 1.0 & $>0.99$ & $>0.99$ & $>0.99$ \\
\hline 0.40 & 50 & 20 & 2.5 & $0.87( \pm 0.04)$ & $0.78( \pm 0.02)$ & $0.83( \pm 0.01)$ \\
\hline 0.08 & 250 & 20 & 12.5 & $0.84( \pm 0.04)$ & $0.64( \pm 0.02)$ & $0.71( \pm 0.05)$ \\
\hline 0.04 & 500 & 20 & 25 & $0.86( \pm 0.02)$ & $0.49( \pm 0.01)$ & $0.61( \pm 0.03)$ \\
\hline 0.02 & 1000 & 20 & 50 & $0.83( \pm 0.00)$ & $0.26( \pm 0.01)$ & - \\
\hline
\end{tabular}

${ }^{\text {a }}$ Recovery results are the average of three separate determinations ( \pm standard deviation). 
Table 4

Spike recovery results for sea water ${ }^{\mathrm{a}}$

\begin{tabular}{|c|c|c|c|c|c|c|}
\hline \multirow[t]{2}{*}{$\mathrm{La}(\mathrm{III})$ spike $\left(\mathrm{mg}^{-1}\right)$} & \multirow[t]{2}{*}{ Initial volume (ml) } & \multirow[t]{2}{*}{ Final volume (ml) } & \multirow[t]{2}{*}{ Enrichment factor } & \multicolumn{3}{|c|}{$\mathrm{La}(\mathrm{III})$ found $\left(\mathrm{mg} \mathrm{l}^{-1}\right)$} \\
\hline & & & & Clinoptilolite & Zeolite Y & Chelex 100 \\
\hline 1.00 & 20 & 20 & 1.0 & $>0.99$ & $>0.99$ & $>0.99$ \\
\hline 0.40 & 50 & 20 & 2.5 & $0.83( \pm 0.03)$ & $0.38( \pm 0.03)$ & $0.83( \pm 0.03)$ \\
\hline 0.08 & 250 & 20 & 12.5 & $0.61( \pm 0.01)$ & $0.47( \pm 0.03)$ & $0.76( \pm 0.02)$ \\
\hline 0.04 & 500 & 20 & 25 & $0.53( \pm 0.01)$ & $0.33( \pm 0.03)$ & - \\
\hline 0.02 & 1000 & 20 & 50 & $0.48( \pm 0.01)$ & - & - \\
\hline \multirow[t]{2}{*}{$\mathrm{Eu}(\mathrm{III})$ spike $\left(\mathrm{mg} \mathrm{l}^{-1}\right)$} & \multirow[t]{2}{*}{ Initial volume (ml) } & \multirow[t]{2}{*}{ Final volume (ml) } & \multirow[t]{2}{*}{ Enrichment factor } & \multicolumn{3}{|c|}{$\mathrm{Eu}(\mathrm{III})$ found $\left(\mathrm{mg} \mathrm{l}^{-1}\right)$} \\
\hline & & & & Clinoptilolite & Zeolite Y & Chelex 100 \\
\hline 1.00 & 20 & 20 & 1.0 & $>0.99$ & $>0.99$ & $>0.99$ \\
\hline 0.40 & 50 & 20 & 2.5 & $0.84( \pm 0.02)$ & $0.49( \pm 0.03)$ & $0.84( \pm 0.03)$ \\
\hline 0.08 & 250 & 20 & 12.5 & $0.61( \pm 0.02)$ & $0.51( \pm 0.02)$ & $0.81( \pm 0.02)$ \\
\hline 0.04 & 500 & 20 & 25 & $0.53( \pm 0.02)$ & $0.34( \pm 0.02)$ & - \\
\hline 0.02 & 1000 & 20 & 50 & $0.42( \pm 0.01)$ & - & - \\
\hline \multirow[t]{2}{*}{ Yb(III) spike $\left(\mathrm{mg} \mathrm{l}^{-1}\right)$} & \multirow[t]{2}{*}{ Initial volume (ml) } & \multirow[t]{2}{*}{ Final volume (ml) } & \multirow[t]{2}{*}{ Enrichment factor } & \multicolumn{3}{|c|}{$\mathrm{Yb}(\mathrm{III})$ found $\left(\mathrm{mg} \mathrm{l}^{-1}\right)$} \\
\hline & & & & Clinoptilolite & Zeolite Y & Chelex 100 \\
\hline 1.00 & 20 & 20 & 1.0 & $>0.99$ & $>0.99$ & $>0.99$ \\
\hline 0.40 & 50 & 20 & 2.5 & $0.85( \pm 0.03)$ & $0.74( \pm 0.01)$ & $0.87( \pm 0.02)$ \\
\hline 0.08 & 250 & 20 & 12.5 & $0.67( \pm 0.02)$ & $0.62( \pm 0.02)$ & $0.75( \pm 0.03)$ \\
\hline 0.04 & 500 & 20 & 25 & $0.56( \pm 0.03)$ & $0.48( \pm 0.02)$ & - \\
\hline 0.02 & 1000 & 20 & 50 & $0.52( \pm 0.03)$ & - & - \\
\hline
\end{tabular}

${ }^{\text {a }}$ Recovery results are the average of three separate determinations ( \pm standard deviation).

An approximate total recovery of $80-90 \%$ could be expected under the experimental conditions employed;

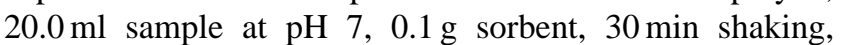
$20.0 \mathrm{ml} \mathrm{HNO}_{3}$ for desorption. This observation also explains the reason of obtaining approximately $20 \%$ lower sensitivity for the matrix-matched standard calibrations compared to the aqueous calibration. It should be mentioned here that any increase in the sample volume may lead to even lower calibration sensitivities to be obtained.

\subsection{Determination of sorption isotherms}

The sorption data of $\mathrm{La}(\mathrm{III})$, Eu(III), and $\mathrm{Yb}$ (III) on clinoptilolite were fitted to Langmuir and Freundlich isotherm models in order to reveal which of them described better the partitioning of the sorbate ions between the liquid and solid phases.

Langmuir isotherm is among the most widely applied isotherm models in sorption studies. This isotherm model assumes that the surface of the sorbent can accommodate only a monolayer of the sorbate ions on energetically equivalent sorption sites. This model assumes also no interaction between the sorbed species, i.e., that the ability of an ion to occupy a certain site is independent of the occupancy on the neighbouring sites [26]. Langmuir isotherm model is given by the equation:

$[C]_{\mathrm{s}}=\frac{C_{\mathrm{m}} K[C]_{1}}{1+K[C]_{1}}$
This equation can be rearranged to get the linear form:

$[C]_{\mathrm{s}}=C_{\mathrm{m}}-\frac{[C]_{\mathrm{s}}}{K[C]_{1}}$

where $[C]_{\mathrm{s}}$ is the equilibrium concentration of sorbate on the solid $\left(\mathrm{mmol} \mathrm{g}^{-1}\right),[C]_{1}$ is the equilibrium concentration of sorbate in the liquid $\left(\mathrm{mmol}^{-1}\right),[C]_{\mathrm{m}}$ is the monolayer sorption capacity, and $K$ is a constant related to the energy of sorption.

Freundlich isotherm model, on the other hand, does not have any restriction on the sorption capacity of the sorbent, and is more appropriate in situations where the sorption sites possess a heterogeneous nature [26]. This model is given by the equation:

$[C]_{\mathrm{s}}=k[C]_{1}^{n}$

The linear form of this equation is:

$\log [C]_{\mathrm{s}}=\log k+n \log [C]_{1}$

Here $[C]_{\mathrm{s}}$ and $[C]_{1}$ are as defined above, ' $n$ ' and ' $k$ ' are Freundlich constants which provide information on the sorption linearity and affinity and are obtained from the slope and intercept of Freundlich plots, respectively.

Plotting the sorption data of $\mathrm{La}(\mathrm{III}), \mathrm{Eu}(\mathrm{III})$, and $\mathrm{Yb}$ (III) on clinoptilolite (Fig. 2a) and using Freundlich model (Fig. 2b) showed that these data obeyed Freundlich isotherm model, as demonstrated by the linear behavior presented in Fig. 2(b) for the three REE cations. Langmuir isotherm equation, on the other hand, did not yield linear behavior for any of these 


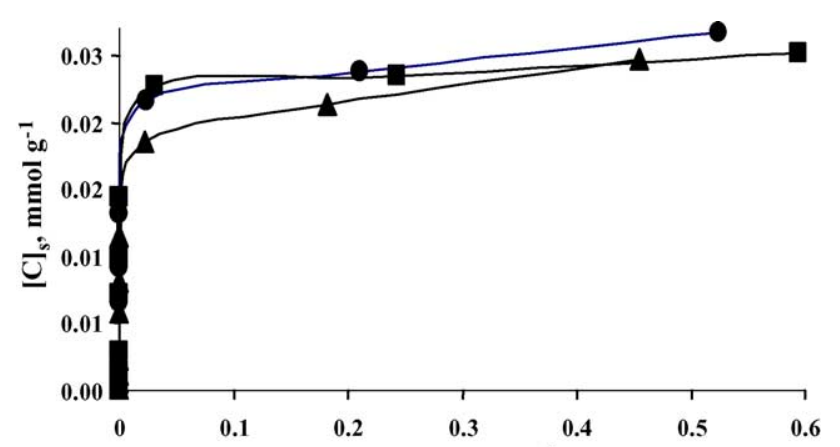

(a)

$[\mathrm{C}]_{1}, \mathrm{mmol} \mathrm{l}^{-1}$

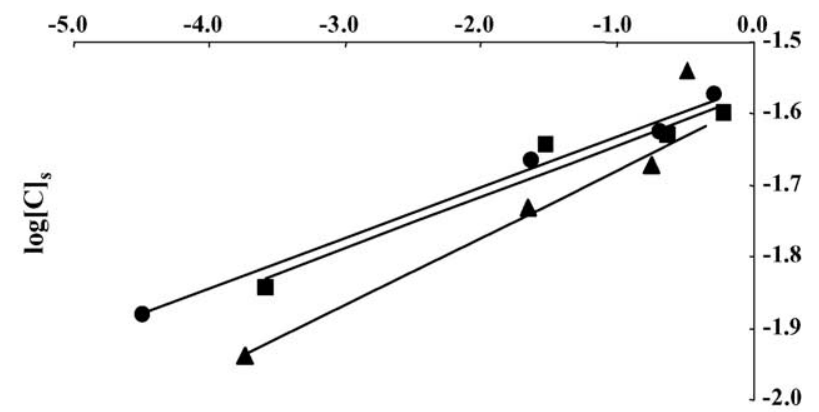

(b)

$\log [\mathrm{C}]_{1}$

Fig. 2. (a) General, (b) Freundlich sorption isotherm for (ם) La(III), $\mathrm{Eu}(\mathrm{III})$, and $(\boldsymbol{\Delta}) \mathrm{Yb}(\mathrm{III})$ on clinoptilolite. Line equations (and correlation coefficients) for Freundlich isotherm model were $y=0.0723 x-1.5717$ $\left(R^{2}=0.9500\right)$ for La, $y=0.0708 x-1.5607\left(R^{2}=0.9916\right)$ for $\mathrm{Eu}$, and $y=0.0938 x-1.5856\left(R^{2}=0.9921\right)$ for $\mathrm{Yb}$.

cations. In general, Langmuir isotherm model is not obeyed when the sorption sites are inequivalent in terms of sorption energy, and when there is a possibility for the interaction between the sorbate species on their fixation sites, the things accounted to by Freundlich isotherms. Multilayer sorption can also cause deviation from Langmuir isotherm equation, but this type of sorption is not plausible in the case of cationsolid interaction where the cations are attracted by the negative charge (either permanent or $\mathrm{pH}$-dependent) on the solid surface.

The values of Freundlich constants, $n$ and $k$, obtained for sorption $\mathrm{La}(\mathrm{III}), \mathrm{Eu}(\mathrm{III})$, and $\mathrm{Yb}(\mathrm{III})$ were: $0.071,0.072$, 0.094 and $0.027,0.028,0.026\left(\mathrm{mmol} \mathrm{g}^{-1}\right)$, respectively. The $n$ values, being far away from unity, indicate that sorption is highly non-linear, which means that the energetic barrier against sorption is fastly increasing as loading is increased. The values of $k$ reveal no significant difference in the affinity of clinoptilolite towards the three ions on a mole basis.

Surveying literature revealed a scarcity in the number of studies devoted to tackle the issue of sorption isotherms of REEs on natural sorbents with specifically no data available on the isotherms describing uptake of those elements by clinoptilolite. Thus, a meaningful comparison is difficult, as the type of fitting isotherm depends closely on the set of experimental conditions and structural details of the solid sorbent.

\subsection{Spike recoveries and preconcentration}

In order to investigate the efficiency of clinoptilolite, zeolite Y and Chelex 100 in the enrichment of REEs from different water types, at different volumes and different concentrations, a set of solutions was prepared and subjected to the usual sorption/desorption process. In these studies, the absolute amount of REEs was fixed at $20.0 \mathrm{mg}$ by spiking the solutions with $0.02-1.0 \mathrm{mg} \mathrm{l}^{-1}$ corresponding to sample volumes of $1000-20 \mathrm{ml}$, respectively. Depending on the volume, appropriate amounts of clinoptilolite, zeolite $\mathrm{Y}$ and Chelex $100(0.1-1.0 \mathrm{~g})$ were added into the solutions. The results are given in Tables 2-4. It should be remembered here that in all calculations, the matrix-matched standard calibration plots were used. Both the initial and final volumes employed during matrix-matching were $20.0 \mathrm{ml}$. As can be seen from the tables, clinoptilolite and Chelex 100 give satisfactory results for all three water types with an enrichment factor of 2.5. In contrast to zeolite Y, these two sorbents also show acceptable performances for ultra pure and bottled drinking water samples even at high initial sample volumes ( $\geq 250 \mathrm{ml}$ ). It is interesting to note that clinoptilolite displays a better performance than the other two sorbents for so-called 'clean' water types, such as ultra pure water and bottled drinking water whereas Chelex 100 is superior for sea water samples being referred to as 'heavy-matrix'.

Another point to consider, is the effect of volume of the standard solutions applied in matrix-matching. All results for higher sample volumes were calculated based on the matrix-matching of $20.0 \mathrm{ml}$ sample. Therefore, these matrixmatching standard calibration graphs are most appropriate for sample volumes of $20.0 \mathrm{ml}$ (first row in the data section of Tables 2-4). The decrease in spike recovery values for higher volumes could have been caused by this fact.

\section{Conclusion}

Possibility of utilizing several sorbents has been demonstrated as alternative matrix removal/preconcentration routes for various environmental water samples prior to the determination of REEs by ICP-AES. It was found that $0.1 \mathrm{~g}$ of the sorbent was adequate for $20.0 \mathrm{ml}$ sample solution containing 0.02-1.0 $\mathrm{mg}^{-1}$ REEs. The kinetic studies have shown that the sorbents can take up more than $95 \%$ of REEs in $1 \mathrm{~min}$. This fast kinetic is promising in terms of the applicability of the sorbents in SPE cartridges, and mini- or micropacked columns. To investigate the sorption mechanism of REEs on clinoptilolite, Langmuir and Freundlich isotherm models were applied. It was found that the sorption data much better obey the Freundlich isotherm model.

It has been also demonstrated that there can be found a suitable sorbent for different applications, and for different $\mathrm{pH}$ values. In addition, the proposed sample treatment method has the potential of being used with more sensitive techniques, such as ICP-MS. With its very fast and superior 
detection capability (lower detection limits), ICP-MS may offer higher preconcentration factors with even smaller volumes.

\section{Acknowledgements}

The authors acknowledge İzmir Institute of Technology for support of this work through the fund 2002 IYTE 35 and also Res.Sci. Oya Altungöz for ICP-AES measurements.

\section{References}

[1] A.M.G. Figueiredo, W. Avristcher, E.A. Masini, S.C. Diniz, A. Abrao, J. Alloys Compd. 344 (2002) 36.

[2] H. Minowa, M. Ebihara, Anal. Chim. Acta 498 (2003) 25.

[3] M.J. Greaves, H. Elderfield, G.P. Klinkhammer, Anal. Chim. Acta 218 (1989) 265.

[4] T.J. Shaw, T. Duncan, B. Schnetger, Anal. Chem. 75 (2003) 3396.

[5] Q. Shuai, B. Hu, Y.C. Qin, W.J. Ruth, Z.C. Jiang, J. Anal. Atom. Spectrom. 15 (2000) 1413.

[6] P. Liang, B. Hu, Z.C. Jiang, Y.C. Qin, T.Y. Peng, J. Anal. Atom. Spectrom. 16 (2001) 863.

[7] M.I. Rucandio, Fresenius J. Anal. Chem. 357 (1997) 661.

[8] R. Djingova, J. Ivanova, Talanta 57 (2002) 821.
[9] M.S. Navarro, H.H.G.J. Ulbrich, S. Andrade, V.A. Janasi, J. Alloys Compd. 344 (2002) 40

[10] O. Vicente, A. Padro, L. Martinez, R. Olsina, E. Marchevsky, Spectrochim. Acta B 53 (1998) 1281.

[11] S. Hirata, T. Kajiya, M. Aihara, K. Honda, O. Shikino, Talanta 58 (2002) 1185.

[12] K. Inagaki, H. Haraguchi, Analyst 125 (2000) 191.

[13] W. Zhu, E.W.B. de Leer, M. Kennedy, G.J.F.R. Alaerts, Fresenius J. Anal. Chem. 360 (1998) 74.

[14] A. Itoh, T. Hamanaka, W. Rong, K. Ikeda, H. Satawari, K. Chiba, H. Haraguchi, Anal. Sci. 15 (1999) 17.

[15] W.R. Pedreira, J.E.S. Sarkis, C. Rodriguez, I.A. Tomiyoshi, C.A. da Silva Queiroz, A. Abrao, J. Alloys Compd. 344 (2002) 17.

[16] X-p. Yan, R. Kerrich, M.J. Hendry, J. Anal. Atom. Spectrom. 14 (1999) 215.

[17] M.B. Shabani, T. Akagi, H. Shimizu, A. Masuda, Anal. Chem. 62 (1990) 2709.

[18] S. Nishihama, T. Hirai, I. Komasawa, J. Solid State Chem. 171 (2003) 101.

[19] O.N. Grebneva, N.M. Kuz'min, G.I. Tsysin, Yu.A. Zolotov, Spectrochim. Acta B 51 (1996) 1417.

[20] P. Möller, P. Dulski, J. Luck, Spectrochim. Acta B 47 (1992) 1379.

[21] S.N. Willie, R.E. Sturgeon, Spectrochim. Acta B 56 (2001) 1707.

[22] K. Dev, R. Pathak, G.N. Rao, Talanta 48 (1999) 579.

[23] I.E. De Vito, A.N. Masi, R.A. Olsina, Talanta 49 (1999) 929.

[24] C. Sarzanini, E. Mentasti, J. Chromatogr. A 789 (1997) 301.

[25] T.P. Rao, R. Kala, Talanta 63 (2004) 949.

[26] M.M. Saeed, M. Ahmed, Anal. Chim. Acta 525 (2004) 289. 